\title{
Opinions of Adults about the Effects of Smoking during Pregnancy and Environmental Tobacco Smoke to the Infant Health in Sakarya, Turkey
}

\author{
Cemile Dede $^{1}$, Nursan Cinar ${ }^{2 *}$, Dilek Menekse ${ }^{2}$, Engin Menekse \\ ${ }^{1}$ Vocational School of Health Sciences, Sakarya University, Sakarya, Turkey \\ ${ }^{2}$ Department of Pediatric Nursing, Faculty of Health Sciences, Sakarya University, Sakarya, Turkey \\ ${ }^{3}$ Department of Pediatrics, Sakarya University Training and Research Hospital, Sakarya, Turkey
}

\begin{abstract}
The aim of this study was to determine the opinions of adults about the effects of smoking during pregnancy and ETS (Enviromental Tobacco Smoke)to the infant health.The sample group of this descriptive study consists of 266 adults who applied to maternity and a children's clinic at a Training and Research Hospital in Sakarya Province and who volunteer to taking part in this study. Written consent from hospital administration and verbal consent from adults who agreed to participate to the study was obtained to perform this study. Data were collected using a questionnaire prepared by researchers in accordance with the literature. The obtained data were analyzed on computer program by using mean, percentages and Chi-square test.79.7\% of participants $(n=212)$ were female, $20.3 \%(n=54)$ were male and the mean age was $\bar{x}=34.10 \pm 9.16$ ( $\min =20$, max $=65) .87 .2 \%$ of all participants, $84.3 \%$ of active smokers and $84.4 \%$ of smokers during pregnancy agreed to the statement that "Smoking during pregnancy and ETS exposure can cause a variety of respiratory diseases". It was determined that $72.6 \%$ of all participants, $68.5 \%$ of active smokers and $75 \%$ of smokers during pregnancy agreed to "Smoking during pregnancy and ETS exposure can cause premature birth". Statistically significant relationship was determined between the genders for this statement $(p<0.05)$. It was determined that knowledge of the participants about the health effects of smoking and ETS exposure on the health of unborn babies and newborn is insufficient. To increase the awareness and knowledge of the society on this issue informative training programs are advised.
\end{abstract}

Keywords: Environmental tobacco smoke; infant health; pregnancy;smoking during pregnancy.

\section{INTRODUCTION}

Active smoking and environmental tobacco smoke (ETS) exposure is one of the most important preventable cause of disease and premature death [1].ETS classified as Group A carcinogen by United States Environmental Protection Agency and consists of two components including second-hand tobacco smoke (SHS) and third-hand tobacco smoke (THS)[2-5]. The mixture of smoke emitted by the smoker's breath and the smoke resulting from the combustion of cigarettes or other tobacco products is called as SHS [1,6].An important part of smoke in indoor environments adheres to the hair, skin, or clothes of smokers, furniture, floors, walls, bedding, carpets, dust and other surfaces and may remain for a long time on these surfaces and this remains considered as THS [5].These residuals can be re-emitted into the gas phase, or react with the oxidants in the environment to produce further pollutants $[5,7,8]$. THS is relatively new concept in the field of tobacco control and yet there are not enough studies on the effects on human health [8-10].

Pregnant women, infants and small children are among the most vulnurable groups toharmful effects of ETS [11-13].It is thought that the developing foetus to be especially sensitive to environmental pollutants including environmental tobacco smoke (ETS) which is one of the most common and important indoor air pollutants $[2,14]$.Maternal smoking or exposure to ETS during pregnancy can cause important pregnancy outcomes such as premature delivery, and low birth weight, which are leading causes of infant death and stillbirth, congenital malformation[11,15].Sudden infant death syndrome(SIDS) risk are also approximately three times more at ETS-exposed infants [11].In a study carried out by Öberg et al. using data from 192 countries in 2004 it was estimated that $40 \%$ of children worldwide were exposed to SHS and $28 \%$ of pediatric deaths were attributable to this 
exposure. [16].The timing and mechanism of this harmful effect is not clear yet. For this reason preventing ETS exposure in women before and during pregnancy is very important [15].

It is pointed out in the 2010 Surgeon General's report that there is "no safe level" of tobacco smoke exposure and implementing $100 \%$ smoke-free policies is recomended[11,17].Opinions, attitudes and practices of adults are important to implement these policies and protect valnurable infants, children and pregnant women from the detrimental effects of ETS.

The aim of this study was to determine the opinions of adults about the effects of smoking during pregnancy and ETS to the infant health.

\section{Materials ANd Methods}

The sample group of this descriptive study consists of 266 adults who applied to maternity and children's clinic at a Training and Research Hospital in Sakarya Province and who volunteer to taking part in this study. The inclusion criterias of participants in the research were identified that participant is between 18-65 years of age, there isn't the lack of communication problems and the illiterate and participant is willing to participate in the study. The couples have not been included to the survey at the same time to avoid duplication and affecting accuracy of the results. One of voluntary person has been selected from the couples. Data were collected using a questionnaire prepared by researchers in accordance with the literature. The form consisted of 18 questions that 6 of them are about sociodemographic characteristics, 5 of them are related with smoking and passive smoking and 7 of them are about the effects of smoking during pregnancy and ETS to the infant health. Written consent from hospital administration and verbal consent from adults who agreed to participate to the study was obtained to perform this study. Data is collected on Thursdays in February 2016.Data collection was carried out in the hospital's policlinic waiting room. Forms were implemented under the supervision of the researchers after a preliminary notification stating the aim and reasons of the study. The data collection process took an average of 15 minutes.

Data from the questionnaire were coded and analyzed using commercial software (IBM SPSS Statistics 20, SPSS Inc. An IBM Corp., Armonk, NY. The obtained data were analyzed on computer program by using mean, percentages and Chi-square test).

\section{RESUlTS AND DisCUSSION}

$79.7 \%$ of participants $(\mathrm{n}=212)$ were female, $20.3 \%(\mathrm{n}=54)$ were male and the mean age was $\bar{x}=34.10$ $\pm 9.16(\min =20, \max =65) .57 .5 \%(n=53)$ of the respondents were primary school graduates, $89.5 \%$ $(\mathrm{n}=238)$ were married, $76.3 \%(\mathrm{n}=203)$ had nuclear family and $28.2 \%(\mathrm{n}=75)$ had two children. According to the statements of respondents $55.6 \%$ of them are non-smoker, $33.5 \%(\mathrm{n}=89)$ are activesmoker and $10.1 \%(n=24)$ ex-smoker. $14.6 \%$ of the women having children $(n=31)$ reported that they smoked during their pregnancy. It was determined that $42.9 \%(\mathrm{n}=114)$ of the married individuals smokes at home and the presence rate of any smoker at home was $48.1 \%(n=128)$.

There is sufficient evidence to infer that nicotine which is the primary component of tobacco adversely affects fetal health[18].In a meta-analysis conducted by Leonardi-Bee et al. SHS exposed pregnant women are estimated to be $23 \%$ more likely to experience stillbirth and $13 \%$ more likely give birth to a child with a congenital malformation [15].Haslam and Draper interviewed with 40 pregnant smokers and with only one exception, they determined that all were able to cite several risks including: cot death, stunted growth, asthma, chest infections, prematurity/low birth weight, miscarriage, stillbirth, congenital deformities and low intelligence. In their study, half of the sample said that they were not worried about these risks [19].

Lai et al.(2013) investigated the perceptions of pregnant smokers and recent quitters concerning the risks of smoking during pregnancy. Their results showed that the quitters had a greater awareness of the threat of smoking to fetal health ( quitter $=6.46>$ smoker $=6.09, p<0.05$; one-tailed), severity of the threat of smoking to fetal health ( quitter $=6.35>$ smoker $=5.72, p<0.01$; one-tailed), and overall perceived risk ( quitter $=6.40>$ smoker $=5.90, p<0.01$; one-tailed) compared with the smoker group. Many pregnant women in their study were aware of the health risks of secondhand smoke to their unborn babies [20].In our study $84.4 \%$ of the smokers during pregnancy agreed to threat of active and passive smoking to the fetal health (Table 1). 
Opinions of Adults about the Effects of Smoking during Pregnancy and Environmental Tobacco Smoke to the Infant Health in Sakarya, Turkey

Table 1. Adults' opinions about the effects of smoking during pregnancy and ETS exposure.

\begin{tabular}{|c|c|c|c|c|c|c|}
\hline & \multirow{2}{*}{$\begin{array}{l}\text { Opinions of } \\
\text { all } \\
\text { participants }\end{array}$} & \multicolumn{3}{|c|}{ Status of smoking in this } & \multicolumn{2}{|c|}{$\begin{array}{l}\text { Status of smoking } \\
\text { during pregnancy }\end{array}$} \\
\hline & & Yes & I quit & No & Yes & No \\
\hline & n (\%) & n (\%) & n (\%) & n (\%) & n (\%) & n (\%) \\
\hline $\begin{array}{l}\text { Smoking } r \text { during } \\
\text { pregnancy and ETS } \\
\text { exposure affects the } \\
\text { unborn baby's health } \\
\text { adversely. } \\
\text { I agree } \\
\text { I don't agree }\end{array}$ & $\begin{array}{l}241(90.6) \\
25(9.4)\end{array}$ & $\begin{array}{l}78(87.6) \\
11(12.4)\end{array}$ & $\begin{array}{l}25(86.2) \\
4(13.8)\end{array}$ & $\begin{array}{l}138(93.2) \\
10(6.8)\end{array}$ & $\begin{array}{l}27(88.4) \\
5(15.6)\end{array}$ & $\begin{array}{l}154(92.2) \\
13(7.8)\end{array}$ \\
\hline $\begin{array}{l}\text { Smoking } r \text { during } \\
\text { pregnancy and ETS } \\
\text { exposure affects the } \\
\text { child's growth and } \\
\text { development negatively. } \\
\text { I agree } \\
\text { I don't agree }\end{array}$ & $\begin{array}{l}238(89.5) \\
28(10.5)\end{array}$ & $\begin{array}{l}76(85.4) \\
13(14.6)\end{array}$ & $\begin{array}{l}24(82.8) \\
5(17.2)\end{array}$ & $\begin{array}{l}138(93.2) \\
10(6.8)\end{array}$ & $\begin{array}{l}26(81.2) \\
6(18.8)\end{array}$ & $\begin{array}{l}153(91.6) \\
14(8.4)\end{array}$ \\
\hline $\begin{array}{l}\text { Smoking } \\
\text { pregnancy and ETS } \\
\text { exposure can cause to } \\
\text { infections by affecting } \\
\text { the unborn baby's } \\
\text { immune system. } \\
\text { I agree } \\
\text { I don't agree }\end{array}$ & $\begin{array}{l}232(87.2) \\
34(12.8)\end{array}$ & $\begin{array}{l}74(83.1) \\
15(16.9)\end{array}$ & $\begin{array}{l}5(86.2) \\
4(13.8)\end{array}$ & $\begin{array}{l}133(89.9) \\
15(10.1)\end{array}$ & $\begin{array}{l}25(78.1) \\
7(21.9)\end{array}$ & $\begin{array}{l}147(88) \\
20(12)\end{array}$ \\
\hline $\begin{array}{l}\text { There is a relationship } \\
\text { between the smoking } \\
\text { during pregnancy and } \\
\text { low birth weight. } \\
\text { I agree } \\
\text { I don't agree }\end{array}$ & $\begin{array}{l}196(73.7) \\
70(26.3)\end{array}$ & $\begin{array}{l}66(74.2) \\
23(25.8)\end{array}$ & $\begin{array}{l}20(69) \\
9(31)\end{array}$ & $\begin{array}{l}110(74.3) \\
38(25.7)\end{array}$ & $\begin{array}{l}26(81.2) \\
6(18.8)\end{array}$ & $\begin{array}{l}123(73.7) \\
44(26.3)\end{array}$ \\
\hline $\begin{array}{l}\text { Smoking } r \text { during } \\
\text { pregnancy and ETS } \\
\text { exposure can cause a } \\
\text { variety of respiratory } \\
\text { diseases. } \\
\text { I agree } \\
\text { I don't agree }\end{array}$ & $\begin{array}{l}232(87.2) \\
34(12.8)\end{array}$ & $\begin{array}{l}75(84.3) \\
14(15.7)\end{array}$ & $\begin{array}{l}26(89.7) \\
3(10.3)\end{array}$ & $\begin{array}{l}131(88.5) \\
17(1.5)\end{array}$ & $\begin{array}{l}27(84.4) \\
5(15.6)\end{array}$ & $\begin{array}{l}144(86.2) \\
23(13.8)\end{array}$ \\
\hline $\begin{array}{lr}\text { Smoking } & \text { during } \\
\text { pregnancy and } & \text { ETS } \\
\text { exposure can } & \text { cause } \\
\text { premature birth. } & \\
\text { I agree } & \\
\text { I don't agree } & \end{array}$ & $\begin{array}{l}193(72.6) \\
73(27.4)\end{array}$ & $\begin{array}{l}61(68.5) \\
28(31.5)\end{array}$ & $\begin{array}{l}21(72.4) \\
8(27.6)\end{array}$ & $\begin{array}{l}111(75) \\
37(25)\end{array}$ & $\begin{array}{l}24(75) \\
8(25)\end{array}$ & $\begin{array}{l}123(73.7) \\
44(26.3)\end{array}$ \\
\hline $\begin{array}{l}\text { Negative effects of } \\
\text { smoking } \\
\text { pregnancy and ETS } \\
\text { exposure can continue } \\
\text { even after the baby is } \\
\text { born. } \\
\text { I agree } \\
\text { I don't agree }\end{array}$ & $\begin{array}{l}227(85.3) \\
39(14.7)\end{array}$ & $\begin{array}{l}73(82) \\
16(18) \\
\end{array}$ & $\begin{array}{l}26(89.7) \\
3(10.3)\end{array}$ & $\begin{array}{l}128(86.5) \\
20(13.5)\end{array}$ & $\begin{array}{l}27(84.4) \\
5(15.6)\end{array}$ & $\begin{array}{l}143(85.6) \\
24(14.4)\end{array}$ \\
\hline
\end{tabular}

Nicotine activates multiple biologic pathways that are relevant to fetal growth and development, immune function, the cardiovascular system, the central nervous system, and carcinogenesis. Nicotine exposure during fetal development has lasting adverse consequences for brain development. It is also contributes to adverse reproductive outcomes, like preterm birth and stillbirth [18]. In utero tobacco smoke exposure is related with abnormal fetal lung development and reduced lung function [21-26].In 
this study $23889.5 \%(n=238)$ of the all participants, $85.4 \%(n=76)$ of the active smokers, and $81.2 \%$ of the smokers during precnancy agreed to the statement that "Smoking during pregnancy and ETS exposure affects the child's growth and development negatively".

ETS exposure is a significant risk factor for respiratory diseases among children and its association with increased prevalence of upper respiratory tract infections has been shown[12,27].Exposure of mother to tobacco smoke cause to exposure of developing fetus to ETS via the umbilical cord blood. These babies' immune system is more deviated against the allergic and asthmatic inflammatory phenotype (ETS) and respiratory health in children [27]. Obtained results of this study revailed that $87.2 \%$ of all participants, $83.1 \%$ of active smokers and $78.1 \%$ of smokers during pregnancy agreed to "Smoking during pregnancy and ETS exposure can cause to infections by affecting the unborn baby's immune system".

In infants and children, prenatal maternal smoking and postnatal ETS exposure cause a dosedependent decrease in lung function and respiratory morbidity [28].In Oh et al.'s study they determined that in utero smoke exposure is associated with poor asthma control and early-onset asthma in subjects assessed at 8 to 17 years of age [21].In Johansson et al.'s study 3 -year-old children exposed both prenatally and postnatally to ETS had reported increased prevalence of wheeze when compared with children born to nonsmoking parents [29]. In Dede et al.'s study (2016)34.6\% of the parents $(n=82)$ smokes, $47.7 \%(n=113)$ of the participant's spouse smokes, at $48.1 \%(n=144)$ there are someone smoking at home[30].In our study it was determined that $87.2 \%$ of all participants, $84.3 \%$ of active smokers and $84.4 \%$ of smokers during pregnancy agreed to the statement that "Smoking during pregnancy and ETS exposure can cause a variety of respiratory diseases".

Smoking during pregnancy is particularly insidious not only for harming the developing fetus but also for its effects manifested inlater life [21,31].Cunningham et al., concluded in their study that maternal smoking during pregnancy and/or exposure to ETS exposure in the first few years of life persist into childhood and may affect the pulmonary function attained throughout the child's life [32].Johansson et al., determined that children exposured to ETS only during prenatal period used more broncodilatating drugs and suffered more from poor sleep [33].

de Assis et al., reported that tobacco exposure during pregnancy has genotoxic effects for both mother and child, and it can be considered an important risk factor for childhood cancer or other geneticrelated diseases [34].Our study showed that $85.3 \%$ of all participants, $82 \%$ of active smokers and $84.4 \%$ of smokers during pregnancy agreed to "Negative effects of smoking during pregnancy and ETS exposure can continue even after the baby is born."

Babies of mothers smoking during pregnancy have about $30 \%$ higher odds of being born prematurely [35].In this study it was determined that $72.6 \%$ of all participants, $68.5 \%$ of active smokers and $75 \%$ of smokers during pregnancy agreed to "Smoking during pregnancy and ETS exposure can cause premature birth". Statistically significant relationship was determined between the genders for this statement $\left(\chi^{2}=4.457, \mathrm{p}=0.03\right) .75 .5 \%(\mathrm{n}=160)$ of female and $61.1 \%$ of male $(\mathrm{n}=33)$ participants agreed to this statement. There was no statistically significant difference between the genders for the other statements.

In a meta-analysis performed by Leonardi-Bee et al. to determine the effects of ETS exposure on birth outcomes it was reported that exposure of non-smoking pregnant women to ETS reduces mean birth weight by $33 \mathrm{~g}$ or more, and increases the risk of birth weight below $2500 \mathrm{~g}$ by $22 \%$ [36]. In Wahabi et al.'s study the mean birth weight of infants of exposed mothers was significantly lower by $35 \mathrm{~g}$, mean birth weight of infants of exposed compared to the infants of unexposed mothers [3].Results of our study denoted that $73.7 \%$ of all participants, $74.2 \%$ of active smokers and $81.2 \%$ of smokers during pregnancy agreed to the statement that "There is a relationship between the smoking during pregnancy and low birth weight".

\section{CONClusion}

It was determined that knowledge of the participants about the health effects of smoking and ETS exposure on the health of unborn babies and newborn is insufficient. About 50\% smoking rate by themselves participants, their spouse or anyone living with them was the most conspicuous findings in terms of smoking and ETS exposure. Resuts showed that gender not an effective factor on the opinions about smoking during pregnancy and ETS exposure on infant health. Among the female 
participants smoking during pregnancy are substantial rate. However, 5 to 1 of the females smoking during pregnancy have opinion that smoking during pregnancy don't affect unborn baby and neonatal health. Smoking or ETS exposure during pregnancy constitutes a major risk to the mother, fetus and infant health. To increase the awareness and knowledge of the society on this issue informative training programs are advised.

\section{LIMITATION}

This data is obtained from a sole city (Sakarya) in Turkey, so it can not be generalized. There should be further studies on different cultures using expanded samples.

\section{ACKNOWLEDGEMENTS}

Also thanks to the participants who participated in this study..

\section{Author Contributions}

N Cinar and C Dede conceived paper, conducted data analysis, wrote manuscript, critically revised manuscript and approved final version. D Menekse oversaw data collection, conducted data analysis, wrote manuscript and approved final version. E Menekse participated in study design, oversaw data collection, approved final version.

\section{REFERENCES}

[1] United States Department of Health and Human Services. USDHHS [Internet]. Atlanta (GA): Centers for Disease Control and Prevention (US); 2006. The Health Consequences of Involuntary Exposure to Tobacco Smoke: A Report of the Surgeon General. [cited 01 June 2016]. Available from: http://www.ncbi.nlm.nih.gov/pubmed/20669524.

[2] U.S. EPA National Ambient Air Quality Standards. (NAAQS) [Internet]. [cited 01 June 2016]. [cited 03 April 2016]. Available from: http://www.epa.gov/air/criteria.html.

[3] Wang Y, Huang Z, Yang M, Wang F, Shuiyuan Xiao S. Reducing environmental tobacco smoke exposure of preschool children: A randomized controlled trial of class-based health education and smoking cessation counseling for caregivers, Int. J. Environ. Res. Public Health 2015; 12: 692-709. doi:10.3390/ijerph120100692.

[4] Protano C, Vitali M. The new danger of thirdhand smoke: Why passive smoking does not stop at secondhand smoke, Environ. Health Perspect. 2011; 119 (10): a422. doi:10.1289/ehp.1103956.

[5] Matt GE, Quintana PJE, Destaillats H, Gundel LA,Sleiman M, SingerBC et al. Thirdhand tobacco smoke: emerging evidence and arguments for a multidisciplinary research agenda. Environ Health Perspect. 2011; 119(9):1218-1226.).

[6] World Health Organization. WHO. [Internet]. France:2007. Protection from exposure to secondhand tobacco smoke: policy recommendations. [cited 01 April 2016]. Available from: http://www.who.int/tobacco/resources/publications/wntd/2007/who_protection_exposure_final_2 5June2007.pdf.

[7] Sleiman M, Gundel LA, Pankow JF, Jacob P, Singer BC, Destaillats H. Formation of carcinogens indoors by surface-mediated reactions of nicotine with nitrous acid, leading to potential thirdhand smoke hazards, Proc Natl Acad Sci USA 2010; 107(15): 6576-6581.

[8] Santos e Silva SI, Bowdler P, Giltrow D, Riddell S, Honeychurch KC. A simple and rapid method for the determination of nicotine in third-hand smoke by liquid chromatography and its application for the assessment of contaminated outdoor communal areas, Drug Test. Analysis 2015; 8. Doi10.1002/dta.1822.

[9] Ferrante G, Simoni M, Cibella F, Ferrara F, Liotta G, Malizia V et al. Third-hand smoke exposure and health hazards in children. Monaldi Arch Chest Dis. 2013; 79(1):38-43.

[10] Dede C, Cinar N. Environmental tobacco smoke and children's health. Iran J Pediatr. 2016; 26(5):e5935.

[11] U.S. Department of Health and Human Services (USDHHS). [Internet]. A report of the Surgeon General: How Tobacco Smoke Causes Disease: What It Means to You. U.S. Department of Health and Human Services, Centers for Disease Control and Prevention, National Center for Chronic Disease Prevention and Health Promotion, Office on Smoking and Health, 2010. 
[cited01 June 2016]. Available from:https://www.cdc.gov/t obacco/data_statistics/sgr/2010/ consumer_booklet/pdfs/consumer.pdf.

[12] Cinar ND, Dede C. Effects of environmental tobacco smoke on the respiratory health of children. Pak. J. Med. Sci. 2010; 26: 223-228.

[13] Samet JM, Chanson D, Wipfli H. The Challenges of limiting exposure to THS in vulnerable populations, Curr Envir Health Rpt 2015; 2: 215-225.

[14] Nieuwenhuijsen MJ, Dadvand P, Grellier J, Martinez D, Vrijheid M. Environmental risk factors of pregnancy outcomes: a summary of recent meta analyses of epidemiological studies, Environmental Health 2013; 12 (6): 2-10.

[15] Leonardi-Bee J, Britton J, Venn A. Secondhand smoke and adverse fetal outcomes in nonsmoking pregnant women: A Meta-analysis. Pediatrics 2011; 127:734-741.

[16] Öberg M, Jaakkola MS, Woodward A, Peruga A, Pruss-Ustun A. Worldwide burden of disease from exposure to second-hand smoke: a retrospective analysis of data from 192 countries. The Lancet. 2011;377(9760):139-46.

[17] Nabi-Burza E, Regan S, Drehmer J, Ossip D, Rigotti N, Hipple B et al. Parents smoking in their cars with children present, Pediatrics2012; 130: 1471-1478

[18] U.S. Department of Health and Human Services. USDHHS [Internet]. Atlanta, GA: 2014. The Health Consequences of Smoking - 50 Years of Progress: A Report of the Surgeon General.U.S. Department of Health and Human Services, Centers for Disease Control and Prevention, National Center for Chronic Disease Prevention and Health Promotion, Office on Smoking and Health. [cited 01 June 2016]. Available from: http://www.ncbi.nlm.nih.gov/pubmed/24455788.

[19] Haslam C, Draper ES. A qualitative study of smoking during pregnancy, Psycholoyg Health \& Medicine,2001; 6(1): 95-99, DOI: 10.1080/713690228).

[20] Lai MC, Chou FS, Yang YJ, Wang CC, Lee MC. Tobacco use and environmental smoke exposure among taiwanese pregnant smokers and recent quitters: Risk perception, attitude, and avoidance behavior, Int. J. Environ. Res. Public Health2013; 10: 4104-4116. doi:10.3390/ijerph10094104

[21] Oh SS, Tcheurekdjian H, Roth LA, Nguyen EA, Sen S, et al. Effect of secondhand smoke on asthma control among black and Latino children, J Allergy Clin Immunol 2012; 129(6): 147883.

[22] Stick SM, Burton PR, Gurrin L, Sly PD, LeSouef PN. Effects of maternal smoking during pregnancy and a family history of asthma on respiratory function in newborn infants. Lancet 1996; 348: 1060-1064.

[23] Wu ZX, Hunter DD, Kish VL, Benders KM, Batchelor TP, Dey RD. Prenatal and early, but not late, postnatal exposure of mice to sidestream tobacco smoke increases airway hyperresponsiveness later in life. Environ Health Perspect 2009; 117:1434-1440.

[24] Wongtrakool C, Roser-Page S, Rivera HN, Roman J. Nicotine alters lung branching morphogenesis through the alpha7 nicotinic acetylcholine receptor. Am J Physiol Lung Cell Mol Physiol 2007;293:L611-8.

[25] Gilliland FD, Berhane K, Li YF, Rappaport EB, Peters JM. Effects of early onset asthma and in utero exposure to maternal smoking on childhood lung function. Am J Respir Crit Care Med 2003;167:917-24.

[26] Gilliland FD, Berhane K, McConnell R, Gauderman WJ, Vora H, Rappaport EB, et al. Maternal smoking during pregnancy, environmental tobacco smoke exposure and childhood lung function. Thorax 2000; 55: 271-6.

[27] Cheraghi M, Salvi S. Environmental tobacco smoke (ETS) and respiratory health in children, Eur J Pediatr 2009; 168:897-905. doi 10.1007/s00431-009-0967-3.

[28] Hwang SH, Hwang JH, Moon JS, Lee DH. Environmental tobacco smoke and children's health, Korean J Pediatr 2012; 55(2):35-41.

[29] Johansson A, Ludvigsson J, Hermansson G. Adverse health effects related to tobacco smoke exposure in a cohort of three-year olds. Acta Paediatr 2008; 97:354-7.

[30] Dede C, Cinar N, Menekse D, Engin Menekse E. Parents' knowledge, attitudes and practices to protect their children from secondhand and thirdhand tobacco smoke. 1st International Black See 
Congress on Environmental Sciences, Giresun, Turkey, August 31- September 3, 2016, Abstract Book, pp:105.

[31] Best D. From the American Academy of Pediatrics: technical report-secondhandand prenatal tobacco smoke exposure. Pediatrics 2009;124:e1017-44

[32] Cunningham J, Dockery DW, Speizer FE. Maternal smoking during pregnancy as a predictor of lung function in children. Am J Epidemiol 1994;139:1139-52.

[33] Johansson AK, Ludvigsson J, Hermansson G. Adverse health effects related to tobacco smoke exposure in a cohort of three-year olds. Acta Pædiatrica 2008; 97: 354-357

[34] de Assis, KRC, Ladeira MSP, Bueno RCA, dos Santos BF, Dalben I, Salvadori DMF. Genotoxicity of cigarette smoking in maternal and newborn lymphocytes. Mutat. Res. Gen. Tox. En.2009; 679: 72-78.

[35] Centers for Disease Control and Prevvention (CDC). [Internet]. Preventing Smoking and Exposure to Secondhand Smoke Before, During, and After Pregnancy. [cited 01 June 2016]. Availablefrom:https://www.cdc.gov/nccdphp/publications/factsheets/prevention/pdf/smoking.pdf

[36] Leonardi-Bee J, Smyth A, Britton J, Coleman T. Environmental tobacco smoke and fetal Health: systematic review and meta-analyses. Arch Dis Child Fetal Neonatal 2008; 93:F351-F361.

[37] Wahabi HA, Alzeidan RA, Fayed AA, Mandil A, Al-Shaikh G, Esmaeil SA. Effects of secondhand smoke on the birth weightof term infants and the demographic profile ofSaudi exposed women, BMC Public Health 2013, 13:341. 